\title{
Simon Baron-Cohen, Teoria zła. O empatii i genezie okru- cieństwa, przekład Agnieszka Nowak, Wydawnictwo Smak Słowa, Sopot 2014
}

Opublikowana przez Wydawnictwo Smak Słowa monografia Simona Barona-Cohena, profesora Uniwersytetu w Cambridge (wydziały psychologii eksperymentalnej i psychiatrii), specjalisty w dziedzinie psychopatologii i psychologii rozwojowej, zajmującego się neuropsychologią autyzmu, psychologią różnic płciowych u ludzi i rolą testosteronu płodowego w rozwoju neuropoznawczym, a także dyrektora Centrum Badań Autyzmu w Cambridge.

Książka składa się z: sześciu rozdziałów poprzedzonych przedmową, dwóch dodatków, obszernej bibliografii, która zwiera pozycje zwarte i artykuły, indeksu nazwisk oraz indeksu rzeczowego. W dwóch dodatkach zostały zamieszczone: kwestionariusze badające współczynnik empatii (EQ) z wersją dla dorosłych i dzieci (s. 167-173), kryteria diagnostyczne zaburzeń osobowości: borderline, antyspołecznego zachowania u młodzieży po 15. roku życia, narcystycznego (bazujące na podręczniku diagnostyczno-statystycznym DSM-IV, wyd. IV).

W rozdziale pierwszym Jak wyjaśnić „zło” i ludzkie okrucieństwo? autor stawia pytanie: czy motywacja naukowa usprawiedliwia okrutne badania na ludziach? S. Baron-Cohen pisze,

Tym, o czym wszyscy ci naukowcy ( lekarze i naukowcy niemieccy w obozach koncentracyjnych) zapomnieli w swojej pogoni za wiedzą, był fakt, że ich „badani” są istotami ludzkimi. To ironia losu, że w naukach o człowieku przedmiot badań (object) określa się po angielsku mianem „podmiotu badanego” (subject), które implikuje wrażliwość na uczucia osoby badanej (s. 21).

W dalszych argumentach badacz używa sformułowania „ci naukowcy”, mając na uwadze osoby przeprowadzające na więźniach obozów koncentracyjnych eksperymenty medyczne, które były przez „tych naukowców” traktowane w kategorii użytecznej praktyki na potrzeby społeczeństwa jako większego dobra.

Simon Baron-Cohen, wyjaśniając fakt istnienia okrucieństwa w obozach niemieckich, odwołuje się nie do pojęcia zła, lecz do empatii. Termin „zło” zastępuje pojęciem „erozja empatii”, której podłoże stanowi traktowanie ludzi jak przedmioty. Z przekonaniem wnikliwego badacza wysnuwa twierdzenie, że kiedy empatia jest wyłączona, osoby działają w trybie ,ja”, a nie „ty”.

$\mathrm{Na}$ stronach swojej książki angielski psycholog odpowiada na pytanie „dlaczego ludzie bywają okrutni wobec swoich bliźnich?" nie w kategoriach filozoficznej refleksji, ale badań naukowych opartych na wiedzy o mózgu człowieka. Simon Baron-Cohen 


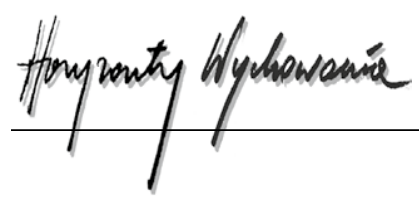

zagłębia się w neurodydaktykę i anatomię ludzkiego mózgu. Dokonuje również analizy czynników biologicznych, społecznych i środowiskowych. Opierając się na własnych badaniach dotyczących spektrum autyzmu i empatii, autor przedstawia krytyczne spojrzenie na naukową teorię współczucia. Wskazuje na potrzebę zmiany sposobu myślenia w zakresie wyjaśniania ludzkiego okrucieństwa i traktowania ludzi, którzy się tego dopuszczają (s. 29). Stawiając wiele pytań, zachęca czytelnika do wnikliwej analizy treści zawartej w rozdziałach książki.

W rozdziale drugim Mechanizm empatii - krzywa normalna S. Baron-Cohen wskazuje, że każdy z nas zajmuje określone miejsce na kontinuum empatii. Za punkt wyjścia przyjmuje zdefiniowanie empatii, która „występuje wtedy, gdy zawieszamy jednoogniskową (single-minded) koncentrację uwagi i przyjmujemy perspektywę dwuogniskową (double-minded)" (s. 31).

Tak przyjęta definicja określa formę, jaką przybiera empatia, oraz wskazuje na taki typ mechanizmu mózgowego, który umożliwia refleksję nad dwoma umysłami. Autor jednak rozszerza definicję empatii, wskazując na proces i treść tego, co się dzieje, gdy empatia jest wyłączona. Twierdzi, że „empatia to zdolność rozpoznawania myśli lub uczuć innej osoby oraz reagowania na jej myśli i uczucia odpowiednią emocją" (s. 32).

Ciekawe jest wprowadzenie przez autora podziału na etapy empatii: rozpoznanie (widzę, dostrzegam) i reakcja (pomagam realnie, współczuję prawdziwie; w pełni rozwinięta faza reakcji emocjonalnej). Autor twierdzi, że empatia połowiczna nie jest empatią. Aby móc dokonywać pomiaru empatii, S. Baron-Cohen ze współpracownikami opracował skalę nazwaną Współczynnikiem Empatii (Empathy Quotient - EQ). To narzędzie odnosi się do dwóch podstawowych części składowych empatii, pozwalając na odróżnienie ludzi mających trudności z empatią od tych, którzy jej nie mają (w: Dodatek 1).

Istotne jest również wskazanie przez autora siedmiu potencjalnych ustawień (szerokich zakresów) mechanizmu empatii na podstawie wyników EQ ze szczególnym wskazaniem tzw. poziomu O („zero empatii”) w przypadku dwóch grup ludzi, którzy mają upodobanie w krzywdzeniu innych oraz takiego upodobania nie przejawiają.

Autor odpowiada na pytanie, co jest czynnikiem sprawczym różnych poziomów mechanizmów empatii. Wskazuje, w odpowiedzi na zależność od funkcjonowania specjalnego obwodu mózgowego, odpowiedzialnego za empatię oraz czynniki środowiskowe lub biologiczne, które mogą zakłócać działanie obwodu empatii w mózgu.

$\mathrm{W}$ rozdziale trzecim Kiedy zerowy poziom empatii jest negatywny S. Baron-Cohen zadaje pytania: „Czym jest zerowy poziom empatii? Co to znaczy być pozbawionym empatii? Czy przekłada się to na to, co niektórzy ludzie nazywają złem?" (s. 55). Wczytując się uważnie, można znaleźć odpowiedź, że

,Zerowy poziom empatii oznacza, że nie masz pojęcia , jak jesteś odbierany przez innych, nie wiesz, jak się z nimi komunikować, nie potrafisz przewidywać ich uczuć i reakcji (...) brak empatii pociąga za sobą głęboko zakorzeniony egocentryzm. (...) Skutek jest taki, że jesteś przeświadczony o słuszności własnych myśli i przekonań, a kiedy ktoś ich nie podziela, uznajesz, że się myli albo jest głupcem (s. 55). 
W dalszych wywodach autor przedstawia nowe ujęcie kategoryzacji używanej na gruncie psychiatrii, interpretując je jako przykłady zerowego poziomu empatii. Łączy je w jedną grupę „zero-negatywną” (nie ma nic pozytywnego), do której zalicza osobowość: borderline typ B, psychopatyczną typ $\mathrm{P}$ z makiaweliczną oraz narcystyczną typ $\mathrm{N}$.

S. Baron-Cohen wskazuje na cechę wspólną wymienionych powyżej typów zero-negatywnych - niedostrzeganie wagi wzajemności relacji międzyludzkich. Ciekawie opisuje typ osobowości N:

Zerowy poziom empatii sprawia, że (ludzie) są głęboko egocentryczni i chociaż ich słowa i czyny mogą obrażać innych lub sprawiać im przykrość, ludzie ci zwykle nie dopuszczają się okrucieństwa. Problem polega raczej na tym, że narcyz - pozbawiony nawet śladu pokory - uważa się za dużo lepszego od innych, jak gdyby miał szczególne zdolności, których innym brakuje. Jego chełpliwość i nieustanna autoreklama są tym, co zraża innych (...) Podczas rozmowy nie próbują zostawić przestrzeni dla drugiej osoby (...) Po prostu przemawiają (...) a w pewnym momencie podejmują decyzję o zakończeniu rozmowy. Nie angażują się w dialog, lecz wygłaszają monologi (s. 91-92).

S. Baron-Cohen pisze, że osoby narcystyczne to zarówno jednostki, które lubią być w centrum uwagi, np. szefowie firm, ale również jednostki wycofane społecznie, mające poczucie, że wszystko im się należy.

Ciekawe jest również odwołanie się przez autora do stanowisk przedstawicieli nurtu psychodynamicznego, którzy uważają, że „odrobina narcyzmu jest niezbędna, normalna i zdrowa, a ci, którzy są jej pozbawieni, nie lubią samych siebie" (s. 92).

Takie dogłębne różnicowanie zachowań wskazanych typów osobowości zero-negatywnej świadczy o wnikliwości badawczej autora, który rozpatruje powyższe w aspekcie przyczyn, nowych metod badań obwodu mózgowego empatii (płaty: czołowy ciemieniowy, skroniowy, zakręt obręczy, przyśrodkową korę przedczołową oraz ciało migdałowate). S. Baron-Cohen dokonuje ich charakterystyki uzupełnionej jednostkowymi przykładami. Wskazuje, w jaki sposób można się stać osobą zero-negatywną. Pozostawia jednak przestrzeń do zastanowienia się dla czytelnika, zadając pytanie: „Dlaczego u jednego człowieka kształtuje się osobowość typu P, a u innego - osobowość typu B lub N?" (s. 93).

Istotne jest również wskazywane przez autora „różnicowanie między chwilowym a trwałym osłabieniem aktywności obwodu empatii” (s. 93), mające na uwadze stany (wywołane przez konkretną sytuację i odwracalne, np. zmęczenie, zniecierpliwienie, stres) i cechy (stałe, utrwalone, niezmienne sytuacyjnie i nieodwracalne). Simon Baron-Cohen kończy rozdział zapytaniem, czy aby na pewno wszystkie formy zerowego poziomu empatii są negatywne? (s. 94).

W rozdziale Kiedy zerowy poziom empatii jest pozytywny S. Baron-Cohen przedstawia kontrowersyjny pogląd, że w co najmniej jednym wypadku brak empatii może być pozytywny. Autor jest przekonany, że

Deficyt empatii może powodować trudności społeczne, ale empatia nie jest jedyną drogą prowadzącą do ukształtowania się kodeksu moralnego i sumienia, dzięki którym człowiek postępuje etycznie. Spotkamy tu ludzi, którzy mają zerowy poziom empatii, ale są 


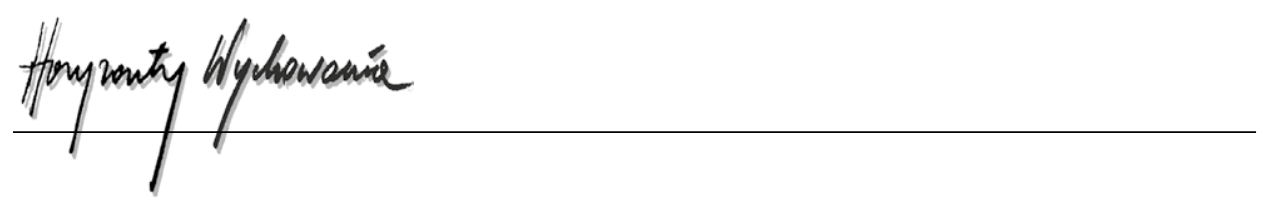

zero-pozytywni (...) Określenie „zero-pozytywni” oznacza, że poza trudnościami z empatią ludzie ci mają niezwykle precyzyjny umysł (s. 95).

Simon Baron-Cohen odnosi twierdzenie „zero-pozytywny” do osób z zespołem Aspergera.

Po pierwsze, w ich wypadku trudności z empatią wiążą się ze szczególnym sposobem przetwarzania informacji przez mózg, co może za sobą pociągać niezwykłe zdolności. Po drugie, sposób, w jaki ich mózg przetwarza informacje, paradoksalnie sprawia, że ludzie ci stają się supermoralni (s. 95).

Co ciekawe, zdaniem Simona Barona-Cohena:

Ludzie ci tak bardzo koncentrują się na prawdzie, że stają się samozwańczymi strażnikami moralności, gdy ktoś łamie zasadę - nawet najbardziej błahą. Oskarżają innych o nieuczciwość, kiedy odkryją choćby najdrobniejszą rozbieżność między ich słowami a czynami (s. 111).

Zaliczając osoby z zespołem Aspergera do grupy „zero-pozytywnej”, autor wyjaśnia, że nie każdy, kto traktuje ludzi przedmiotowo, celowo wyrządza im krzywdę. Wskazuje jednocześnie na fakt, iż deficytowi empatii u takich osób towarzyszą nadzwyczajne zdolności do rozpoznawania wzorów (prawidłowości) i systematyzowania informacji. Simon Baron-Cohen twierdzi, że

\begin{abstract}
Społeczeństwo ma wielki dług wdzięczności wobec tych, którzy wprowadzają innowacje w technice, muzyce, naukach przyrodniczych, matematyce, historii, filozofii, inżynierii oraz $w$ innych dziedzinach opartych na systematyzowaniu. Fakt, że tacy ludzie mogą mieć problemy z empatią, jest dodatkowym powodem, z jakiego nasze społeczeństwo powinno być przyjaźnie nastawione do osób zero-pozytywnych (s. 115-116).
\end{abstract}

Autor wskazuje na fakt, iż

ludzie z Zespołem Aspergera często pierwsi śpieszą na pomoc osobie, która ich zdaniem jest traktowana niesprawiedliwie, ponieważ każda niesprawiedliwość stanowi naruszenie systemu moralnego, który skonstruowali zgodnie z zasadami prostej logiki (s. 116).

S. Baron-Cohen, dokonując interpretacji zjawiska empatii „zero-pozytywnej”, odnosi się również do znaczenia czynników genetycznych. W rozdziale Gen empatii autor monografii już na samym początku zadaje pytanie - „Dlaczego jeden człowiek staje się zero-negatywny, a inny zero-pozytywny?” (s. 117). Przygląda się też najnowszym danym empirycznym przemawiającym za tym, że czynniki środowiskowe oddziałują w interakcji z „genami empatii”. Zapis w cudzysłowie jest świadomym zabiegiem, ponieważ geny nie mogą kodować zjawiska tak złożonego jak empatia, ale są powiązane z wynikami uzyskiwanymi na skalach empatii.

W rozdziale szóstym pt. Refleksje na temat ludzkiego okrucieństwa S. Baron-Cohen zaprezentował dziesięć nowych idei, m.in. wskazał, że każdy z nas lokuje się gdzieś 
na kontinuum empatii. Dokonał interpretacji „wewnętrznego garnca złota” (idea Johna Bowlby'ego - pojęcie wczesnego przywiązania), wskazał na istnienie genów odpowiedzialnych za empatię. Autor podkreślił, że tylko umiarkowany poziom empatii ma największą wartość przystosowawczą, a logika i empatia nie wykluczają się wzajemnie (s. 162).

Monografia S. Barona-Cohena skupia się na roli empatii w kategoriach niezbędnego zasobu prawidłowego funkcjonowania świata. Jest próbą określenia źródeł i uwarunkowań empatii, łącznie z wpływem hormonów, genów, środowiska, wczesnych doświadczeń dziecięcych.

Książka Simona Barona-Cohena stanowi zmierzenie się z kontrowersyjnymi pytaniami neuronauki społecznej: Co sprawia, że ktoś jest zły? Czy mózg ma z tym coś wspólnego? Autor przedstawia nową teorię zła, dokonując jego naukowego wyjaśnienia. Wzbudza refleksję nad rozumieniem okrucieństwa w kategorii braku empatii. Skłania również do refleksji nad koncepcją empatii, cennego zasobu społecznego.

Monografię można polecić szerokiemu gronu czytelników, szczególnie mając na uwadze specjalistów łączących teorię z praktyką w pracy pedagogicznej, socjalnej, psychologicznej, socjologicznej oraz medycznej. Stanowi też istotną pomoc dydaktyczną dla studentów i doktorantów dyscyplin społecznych i humanistycznych.

Styl pisania autora jest zrozumiały i rzeczowy. Nie jest przeładowany specjalistycznym językiem, dlatego odbiór tekstu jest czytelny dla odbiorcy niebędącego specjalistą. Przytaczane przez autora studia przypadków, logiczna argumentacja wynikająca z badań naukowych S. Barona-Cohena umożliwia łatwiejsze zrozumienie omawianych teorii. Istotny jest również fakt, iż autor omawia problematykę i mechanizm zła w sferze nauki, a nie religii. Stawia pytania filozoficzno-etyczne, ale w charakterze indywidualnej zadumy nad kondycją współczesnych społeczeństw, w których widoczny jest brak empatii. W publikacji można odnaleźć styl myślenia odkrywczego autora, który stawia odważne koncepcje i intrygujące tezy. Po lekturze książki zainteresowany czytelnik może wykonać na własny użytek test na Współczynnik Empatii, który znajduje się w Dodatku.

W świetle przytoczonych argumentów z pełnym przekonaniem o jej odkrywczych zasobach poznawczych mogę polecić książkę do przeczytania. 